Arturo Cortes-Cuevas ${ }^{*}$

José Arce-Menocal ${ }^{2}$

Ernesto Ávila-González ${ }^{1}$

Carlos López-Coello ${ }^{1}$

1FUniversidad Nacional Autónoma de México, Facultad de Medicina Veterinaria y Zootecnia

${ }^{2}$ Universidad Michoacana de San Nicolás de Hidalgo

*Corresponding author: Email address:

cortescuevasarturo@yahoo.com
Accepted: 2019-09-30

Published: 2019-09-30

Additional information and declarations can be found on page 11 (c) Copyright 2019
A. Cortes et al.

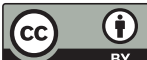

Distributed under Creative Commons CC-BY 4.0

\section{Phosphorus bioavailability, amino acid digestibility and metabolizable energy of broiler chick diets supplemented with low-oil distiller's dried grains with solubles}

\begin{abstract}
Phosphorus (P) bioavailability, crude protein (CP), amino acid (AA) digestibility, and apparent metabolizable energy $\left(\mathrm{AME}_{n}\right)$ were determined in broiler chick diets, supplemented with one of two low-oil distiller's dried grains with solubles (oil contents 6.54\% and 5.35\% for DDGS A and B, respectively). Diets were provided ad libitum in a mash form, from days 8 to 21 of age. In Experiment 1, one day old male broiler chicks $(n=210)$ were assigned to one of 7 treatments, with 3 replicates of 10 birds each. Animals in treatment 1 ( $\mathrm{T} 1)$ were fed a basal diet formulated to be deficient in nonphytate P (0.14\%). Birds in T2 and T3 received the basal diet supplemented with $0.05 \%$ or $0.10 \%$ of $P$ from monodicalcium phosphate (MCP), respectively. Phosphorus from DDGS was added to diets in T4 (0.05\% from DDGS $A)$, T5 (0.1\% from DDGS A), T6 (0.05\% from DDGS B) and T7 (0.1\% from DDGS B). Percent of inclusion of DDGS was dictated by total $\mathrm{P}$ content as determined by chemical analyses. Growth performance and $\mathrm{P}$ intake were assessed in all birds. Phosphorus bioavailability was determined using the slope ratio assay, with tibia ash as the response variable. For Experiment 2, one-day-old male broiler chicks ( $n=200$ ), were assigned to 5 treatments with 4 replicates of 10 birds each. A sorghum-soya control diet was given to animals in T1. Treatments 2 and 3 included this same diet supplemented with either $5 \%$ or $10 \%$ of DDGS A. Birds in T4 and 5 received the control diet with either- $5 \%$ or $10 \%$ of DDGS B. Amino acid digestibility was measured from ileal contents in 7 euthanized birds from each group at day 21. Apparent metabolizable energy was determined in oven dried feces from all animals during the last 3 days of the experiment. Weight gain and feed consumption
\end{abstract}

\section{Cite this as:}

Cortes-Cuevas A, Arce-Menocal J, Ávila-González E, López-Coello C. Phosphorus bioavailability, amino acid digestibility and metabolizable energy of broiler chick diets supplemented with low-oil distiller's dried grains with solubles. VetMéxOA. 2019;6(3).doi: 10.22201/fmvz.24486760e.2019.3.543. 
increased $(P<0.001)$ with larger inclusion of dietary $P$ in birds from experiment 1. Relative P bioavailability for DDGS A and B was $72 \%$ and $86 \%$ respectively, from a P total content of $0.85 \%$ and $0.94 \%$. Growth performance was similar for all treatment groups in experiment $2(P>0.05)$. The average apparent ileal amino acid digestibility coefficient for DDGS A 76.5\% and B was $76.4 \%$. No differences were found for essential AA coefficients between the two DDGS $(P>0.05)$. The $A_{M} E_{n}$ values on a dry matter basis were 2828 and $2854 \mathrm{kcal} / \mathrm{kg}$ for DDGS A and B, respectively.

Keywords: Amino acids, lleal digestibility, Apparent metabolizable energy, Available phosphorus, Low-oil DDGS 


\section{Introduction}

More than 142.7 million tons of corn were directed to ethanol production worldwide in 2018. Derived from this process, thirty million tons of distiller's dried grains with solubles (DDGS), which are the nutrient rich co-product of dry-milled ethanol production, reached the trading market for animal feeding. ${ }^{.}$Concurrently, Mexico imported close to $22 \%$ of the total DDGS production from the USA. At present, most ethanol production plants are removing oil from DDGS by spinning the soluble portion at the end of the fermentation process. This oil is then used for biodies$\mathrm{el}$, and the remaining co-product is known as oil-extracted or low-oil DDGS. ${ }^{2}$ These low-oil DDGS have close to 50\% less oil than conventional DDGS, and a somewhat higher protein content. ${ }^{2}$ However, assessment of the nutritional value of oil extracted DDGS for use in livestock feed is scarce. Kim et al. ${ }^{3}$ reported a phosphorus (P) bioavailability of $60 \%$ and $56 \%$ for DDGS containing $10 \%$ and $2.9 \%$ of oil respectively. Conversely, P bioavailability for conventional DDGS has been reported as being close to 75\%. Moreover, amino acid (AA) digestibility, has been shown to be similar between low-oil and conventional DDGS, with a lysine digestibility of 69\% in DDGS samples ranging from 9 to $13.2 \%$ of oil content. ${ }^{4-6}$ Lastly, few studies have assessed the energy value of low-oil DDGS. Therefore, the objective of the current study was to evaluate $P$ bioavailability, crude protein content (CP), AA ileal digestibility, and apparent metabolizable energy (AMEn) of two low-oil DDGS samples added to sorghum-soybean meal-based diets for broiler chicks.

\section{Materials and methods}

Experiment 1 was designed to evaluate $\mathrm{P}$ bioavailability of low-oil DDGS (relative to monodicalcium phosphate -MCP-), when added to broiler chick diets. Experiment 2 aimed to determine $\mathrm{AA}$ digestibility and $\mathrm{AME}_{\mathrm{n}}$ of two oil extracted DDGS samples, and to evaluate their feeding value at increasing practical levels of inclusion. ${ }^{7}$

\section{Laboratory analyses}

The chemical composition of the two low-oil DDGS used in this study is presented in Table 1. Crude protein (CP) and total AA content in diets were determined in duplicates according to the $982.30 \mathrm{AOAC}^{8}$ method. Tryptophan was measured by alkaline hydrolysis with sodium hydroxide, followed by high performance liquid chromatography (HPLC). To assess methionine and cysteine, samples were previously subjected to oxidation with performic acid. The remaining AA were analyzed by acid hydrolysis $\left(110^{\circ} \mathrm{C}-\mathrm{HCl}, 6 \mathrm{~N}\right)$ for $24 \mathrm{~h}$, and further subjected to ionic exchange chromatography.

\section{Poultry husbandry}

Animal handling, housing, and euthanasia were approved by the Bioethics and Animal Welfare Committee of the Faculty of Veterinary Medicine of the National Autonomous University of Mexico. One day old chicks were obtained from a commercial hatchery and vaccinated against Marek's disease using eye drops. At 10 days of age, broilers were also vaccinated against Newcastle by subcutaneous injection. 
Table 1. Chemical composition of two low-oil distiller's dried grain with solubles (DDGS).

\begin{tabular}{|l|r|r|}
\hline \multicolumn{1}{|c|}{ Analyses } & DDGS A (\%) & DDGS B (\%) \\
\hline Dry matter & 95.45 & 95.05 \\
\hline Moisture & 4.55 & 4.95 \\
\hline Crude protein & 28.05 & 27.02 \\
\hline Ether extract & 6.54 & 5.39 \\
\hline Ash & 5.40 & 5.26 \\
\hline Crude fiber & 8.05 & 8.43 \\
\hline Nitrogen free extract & 47.41 & 48.96 \\
\hline Calcium & 0.12 & 0.05 \\
\hline Total phosphorus & 0.85 & 0.94 \\
\hline Phytate phosphorus & 0.27 & 0.31 \\
\hline Nonphytate P & 0.58 & 0.63 \\
\hline \multicolumn{1}{|c|}{ Gross energy/ kcal/kg } & 4532 & 4394 \\
\hline
\end{tabular}

Battery cages with wire floors, fitted with individual drinkers and feeders, were used for animal housing. All birds received a sorghum-soybean meal-based diet from days 1 to 7 of age, formulated to comply with nutritional the requirements specified by the Ross 308 manual, ${ }^{9}$ and according to the primary breeder recommendations before starting Experiment 1.

\section{Experimental design \\ Experiment 1}

Two hundred and ten one-day-old Ross 308 male broiler chicks were individually weighed and sorted to have a similar animal weight distribution in every replicate. Birds were assigned to 7 dietary treatments, from days 8 to 21 of age, with 3 replicates of 10 birds each. Feed was provided ad libitum in a mash form. Cellulose was replaced in experimental diets by $\mathrm{P}$ from MCP or DDGS (A or B). Chicks in treatment 1 were given a basal diet formulated to be deficient in nonphytate $P(0.14 \%)$ (table 2). Birds in treatments 2 and 3 received this same basal diet supplemented with $0.05 \%$ or $0.10 \%$ of $P$ from MCP, respectively. Basal diets in treatments 4 and 5 were supplemented with $0.05 \%$ or $0.10 \%$ of $P$ from DDGS-A, respectively. In treatments 6 and $7,0.05 \%$ or $0.10 \%$ of P from DDGS-B were, respectively, added to the control diet. Percentage of inclusion of both DDGS was dictated by their respective total $\mathrm{P}$ content, as determined by chemical analyses.

Feed consumption, weight gain, and feed conversion (measured as the ratio of feed consumed:weight gained) were measured daily throughout the experimental period. At $d 21$ of age, 6 birds per pen were euthanized by $\mathrm{CO}_{2}$ asphyxiation. The left tibias were subsequently collected, fat-extracted, dried, and processed for bone ash determination (method 932.16 AOAC). ${ }^{8}$

\section{Experiment 2}

Two hundred one day old male Ross 308 broiler chicks were randomly assigned to 5 dietary treatments, with 4 replicates of 10 birds each. Feed was provided ad libitum from 8 to $21 \mathrm{~d}$ of age in a mash form. Treatments consisted of a control sorghum-soybean meal diet (T1), or this same diet supplemented with either 5\% 
Table 2. Ingredients and nutrient content of the sorghum-soya based control diet formulated to be deficient in nonphytate phosphorous (P) (0.14\%) used in Experiment 1.

\begin{tabular}{|c|c|}
\hline Ingredients & Inclusion, \% \\
\hline Sorghuma & 38.050 \\
\hline Soybean meala & 38.720 \\
\hline Soybean oil & 8.000 \\
\hline Calcium carbonate & 2.500 \\
\hline Cellulose & 11.573 \\
\hline Salt & 0.382 \\
\hline DL-methionine & 0.314 \\
\hline L-lysine $\mathrm{HCl}$ & 0.146 \\
\hline Vitamin and mineral premix ${ }^{b}$ & 0.200 \\
\hline Choline chloride 60\% & 0.100 \\
\hline Antioxidant BHT & 0.015 \\
\hline Nutrient & Calculated analysis \\
\hline Protein & 22.00 \\
\hline Digestible lysine & 1.39 \\
\hline Digestible methionine + cysteine & 0.92 \\
\hline Calcium & 1.02 \\
\hline Nonphytate P & 0.14 \\
\hline $\mathrm{ME}, \mathrm{kcal} / \mathrm{kg}$ & 2950 \\
\hline
\end{tabular}

a Analyzed total phosphorus values were $0.35 \%$ and $0.70 \%$ for sorghum and soybean meal ingredients, respectively. Calculated nonphytate phosphorus values were $0.12 \%$ and $0.24 \%$ for these same ingredients, respectively.

b Provides: vitamin $\mathrm{A}_{\text {, }} 6000000 \mathrm{Ul}$; vitamin $\mathrm{D}_{3}$, 1,500,000 Ul; vitamin $\mathrm{E}_{1}$ 12,000 Ul; vitamin $\mathrm{K}_{3}, 2.0$ g; riboflavin, 8 g; vitamin $\mathrm{B}_{12}$, 0.120 g; pyridoxine, 6.0 g; calcium pantothenate, 26.0 g; niacin, 50 g; biotin, 0.126 g; choline chloride, 500 g; selenium, 0.2 g; cobalt, 0.1 g; iodine, 0.3 g; copper, 10 g; zinc, 50 g; iron, 100 g; manganese, 100 g; excipient qs 2,000 g.

or 10\% of DDGS A (T2 and T3 respectively) or DDGS B (T4 and T5 respectively). Composition of diets is presented in Table 3. Measured values for crude protein and total amino acids, as determined by chemical analyses in both DDGS, were used for diet formulation.

Titanium dioxide (TiO2, 0.2\%) was added to diets as an indigestible marker ${ }^{10}$ to assess raw protein and AA digestibility. Its presence in diets and within ileal contents was analyzed according to the method described by Lomer et al. ${ }^{11}$ and read on a Varian inductively coupled plasma mass spectrometer (Varian Inc., Palo Alto, CA). Digestibility coefficients were calculated by the following formula:

$A D_{A A}=100-[100 \times] \frac{(A A) \text { content } x(\mathrm{TiO} 2) \text { diet }}{(\mathrm{AA}) \text { diet } \times(\mathrm{TiO} 2) \text { content }}$

Where:

$\mathrm{AD}_{\mathrm{AA}}=$ individual $\mathrm{AA}$ apparent digestibility (percentage)

$[\mathrm{AA}]_{\text {content }}=\mathrm{AA}$ concentration in ileal contents

$[\mathrm{AA}]_{\text {diet }}=\mathrm{AA}$ concentration in diet

$[\mathrm{TiO} 2]_{\text {content }}=$ Titanium dioxide concentration in ileal contents

$[\mathrm{TiO} 2]_{\text {diet }}=$ Titanium dioxide concentration in diet 
Table 3. Nutrient content and chemical analyses of diets used in Experiment 2.

\begin{tabular}{|c|c|c|c|c|c|}
\hline Ingredient & Control & 5\% DDGS-A & $10 \%$ DDGS-A & 5\% DDGS-B & 10\% DDGS-B \\
\hline Sorghum & 593.985 & 568.117 & 542.246 & 566.073 & 538.158 \\
\hline Soybean meal & 339.214 & 314.745 & 290.276 & 314.934 & 290.654 \\
\hline DDGS & ---- & 50.000 & 100.000 & 50.000 & 100.00 \\
\hline Soybean oil & 22.797 & 23.197 & 23.598 & 25.041 & 27.285 \\
\hline Monodicalcium phosphate & 20.230 & 19.068 & 17.907 & 18.938 & 17.647 \\
\hline Calcium carbonate & 12.256 & 12.859 & 13.463 & 13.013 & 13.770 \\
\hline Salt & 3.788 & 3.834 & 3.881 & 3.836 & 3.884 \\
\hline DL-methionine & 2.546 & 2.481 & 2.416 & 2.480 & 2.415 \\
\hline L-lysine $\mathrm{HCl}$ & 2.034 & 2.549 & 3.063 & 2.535 & 3.037 \\
\hline Vitamin premix $x^{a}$ & 1.000 & 1.000 & 1.000 & 1.000 & 1.000 \\
\hline Mineral premix ${ }^{a}$ & 0.500 & 0.500 & 0.500 & 0.500 & 0.500 \\
\hline Choline chloride 60\% & 1.000 & 1.000 & 1.000 & 1.000 & 1.000 \\
\hline Zinc bacitracin 10\% & 0.300 & 0.300 & 0.300 & 0.300 & 0.300 \\
\hline Titanium dioxide & 0.200 & 0.200 & 0.200 & 0.200 & 0.200 \\
\hline Antioxidant BHT & 0.150 & 0.150 & 0.150 & 0.150 & 0.150 \\
\hline Total & 1000.0 & 1000.0 & 1000.0 & 1000.0 & 1000.0 \\
\hline \multicolumn{6}{|c|}{ Chemical analysis } \\
\hline Protein, \% & 22.0 & 22.0 & 22.0 & 22.0 & 22.0 \\
\hline $\mathrm{ME}, \mathrm{kcal} / \mathrm{kg}$ & 3000 & 3000 & 3000 & 3000 & 3000 \\
\hline Digestible methionine + cysteine, $\%$ & 0.85 & 0.85 & 0.85 & 0.85 & 0.85 \\
\hline Digestible lysine, \% & 1.20 & 1.20 & 1.20 & 1.20 & 1.20 \\
\hline Calcium, \% & 1.00 & 1.00 & 1.00 & 1.00 & 1.00 \\
\hline Nonphytate P, \% & 0.50 & 0.50 & 0.50 & 0.50 & 0.50 \\
\hline
\end{tabular}

At $21 \mathrm{~d}$ of age, 7 birds per treatment group were euthanized by $\mathrm{CO}_{2}$ asphyxiation and used for ileal digesta collection. Briefly, an intestinal segment between Meckel's diverticulum and the ileocecal junction was dissected, ileal contents were removed, stored in a plastic bag, and immediately frozen until analyzed. For CP and AA determination, digesta samples were freeze-dried and analyzed at the Evonik Industries laboratory, by ionic exchange chromatography with post-column ninhydrin derivatization. ${ }^{12}$

Apparent metabolizable energy was determined in oven dried feces $\left(65^{\circ} \mathrm{C}\right.$ for 72 hours) from all animals during the last three days of the experiment. The Leeson and Summers procedure was used, ${ }_{10}^{10}$ correcting at 0\% nitrogen retention, and using the following formula:

AMEn= ME control diet $-\frac{(\text { ME control diet }- \text { ME diets with DDGS) }}{\% \text { DDGS }}$

Apparent ileal digestibility coefficients for CP and AA were also calculated using the Leeson and Summers ${ }^{10}$ formula. Diet raw energy was measured in both feed and feces samples with Parr's calorimetric pump (Parr Instruments, Moline, IA), and nitrogen content was assessed by the Kjeldahl procedure (AOAC standardized method 982.30). ${ }^{8}$ 


\section{Statistical analyses}

\section{Experiment 1}

Growth performance data was analyzed by ANOVA for a completely randomized design and the Tukey's multiple comparison test. Phosphorus consumption and tibia bone ash content were fitted into a linear regression model. Phosphorus Bioavailability was assessed by the slope ratio methodology, ${ }^{13}$ using tibia bone ash as the dependent variable $(Y)$ and $P$ consumption as the independent variable $(X)$. The MCP consumption was used as the standard line $\left(\beta_{1} X_{1}\right)$ and $P$ consumption from each DDGS source was the tested response $\left(\beta_{2} X_{2}+\beta_{3} X_{3}\right)$.

\section{Experiment 2}

Body weight gain, feed consumption, feed conversion, AA digestibility and AMEn were analyzed by ANOVA for a completely randomized design and the Tukey's post hoc test.

All statistical analyses were conducted using the SPSS statistical package for Windows version 17 SPSS Inc. ${ }^{13}$ Statistical differences were set at $\mathrm{P}<0.05$.

\section{Results Experiment 1}

Weight gain, feed consumption, P consumption, and tibia bone ash are presented in Table 4. Body weight gain and feed consumption increased as dietary $P$ increased $(P<0.05)$. The highest weight gain and feed consumption were observed in the birds fed the diets with $0.10 \%$ of supplemented P. Phosphorus consumption also increased $(P<0.01)$ as dietary $P$ increased from MCP or DDGS ( $A$ or B). Tibia bone ash content was greater when diets were supplemented with $0.10 \% \mathrm{P}$.

Tibia bone ash as an indicator of $\mathrm{P}$ consumption can be explained by the following equation: $Y=27.614+0.007 \times 1+0.005 \times 2+0.006 \times 3$; where $X 1$ relates to $P$ consumed from MCP (T1, T2, and T3), whereas $X 2$ and $X 3$ represent $P$ intake from diets containing DDGS A or DDGS $B$ respectively. Phosphorus bioavailability was estimated as $72 \%$ and $86 \%$ for DDGS A and B respectively, when compared to MCP (100\%) (Figure 1).

\section{Experiment 2}

Weight gain, feed consumption and feed conversion were similar between groups (P > 0.05) (Table 5). Total amino acid content and digestibility coefficients were similar $(P>0.05)$ between diets supplemented with DDGS (Table 6).

\section{Discussion}

Weight gain of broiler chicks in experiment 1 increased when $\mathrm{P}$ was added to a sorghum-based diet, formulated to be deficient in nonphytate. This result agrees with those of previous studies where corn-soybean meal based diets were supplemented with Peither from either MCP or DDGS.3,4,5,14 Moreover, tibia bone ash and $\mathrm{P}$ consumption increased with greater $\mathrm{P}$ inclusion in diets (from MCP or oil 
Table 4. Weight gain (g/bird), feed intake (g/bird), feed efficiency (g:g), phosphorus consumption (mg/bird), and tibia bone ash (\%) of broiler chicks fed $0.05 \%$ or $0.1 \%$ of phosphorus from either monocalcium phosphate or one of two DDGS samples from d 8 to 21 of age (Experiment 1).

Treatment

\section{Phosphorus content, \%}

1. Basal diet

2. $+0.05 \%$ from MCP

3. $+0.10 \%$ P from MCP

4. $+0.05 \%$ P from DDGS A

5. $+0.10 \%$ P from DDGS A

6. $+0.05 \%$ P from DDGS B

7. $+0.10 \%$ P from DDGS B
0.140

0.190

0.240

0.190

0.240

0.190

0.240

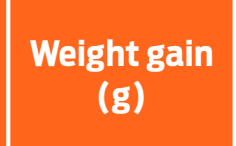

$644 \pm 40.2^{a}$

$285 \pm 5.19^{a}$

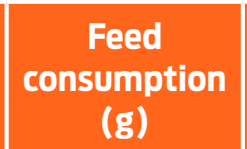

$886 \pm 27.6^{b} \quad 331 \pm 28.7^{a, b}$

$1440 \pm 35.7^{c}$

$447 \pm 10.8^{c}$

$1008 \pm 27.7^{b} \quad 343 \pm 16.5^{a, b}$

$1337 \pm 49.7^{c} \quad 405 \pm 22.5^{b, c}$

$1026 \pm 10.2 b \quad 339 \pm 4.16 a b$

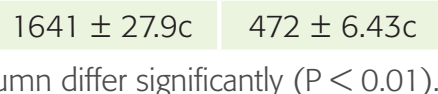

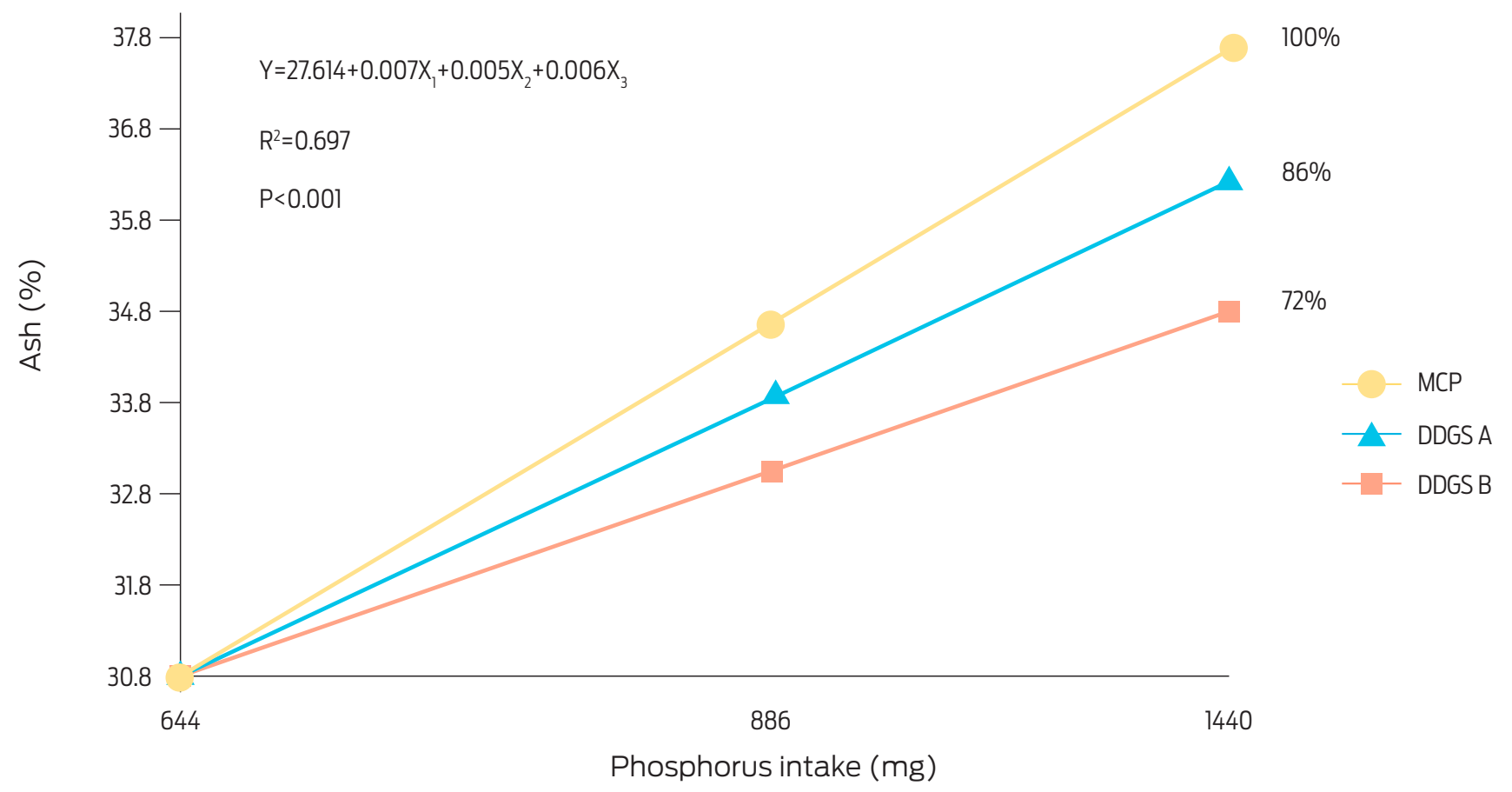

Figure 1. Tibia bone ash content (\%) in 21-day old broiler chicks fed increasing phosphorus levels from monodicalcium phosphate or one of two DDGS samples from 8 to 21 days of age. 
Table 5. Weight gain ( $\mathrm{g}$ ), feed consumption ( $\mathrm{g} /$ bird), and feed conversion $(\mathrm{g} / \mathrm{g})$ of broiler chicks fed a sorghum based control diet or this same diet supplemented with either $5 \%$ or $10 \%$ of two low-oil DDGS from days 8 to 21 of age (Experiment 2). ${ }^{\mathrm{a}}$

\begin{tabular}{|c|c|c|c|}
\hline Treatments & Weight gain (g) & Feed consumption (g) & Feed conversion (g/g) \\
\hline 1. Control & $369 \pm 17.4$ & $741 \pm 10.0$ & $2.01 \pm 0.98$ \\
\hline 2. 5\% DDGS A & $333 \pm 11.2$ & $732 \pm 10.6$ & $2.20 \pm 0.91$ \\
\hline 3. 10\% DDGS A & $336 \pm 3.25$ & $732 \pm 23.8$ & $2.17 \pm 0.53$ \\
\hline 4. 5\% DDGS B & $337 \pm 6.58$ & $746 \pm 7.54$ & $2.21 \pm 0.44$ \\
\hline 5. 10\% DDGS B & $339 \pm 4.64$ & $738 \pm 5.63$ & $2.17 \pm 0.27$ \\
\hline
\end{tabular}

a Means \pm SEM.

extracted DDGS), as previously observed by other authors. $5,4,3,14$ However, these studies used conventional DDGS to supplement corn-soybean meal based diets.

There were no differences in mean weight gain of chicks between treatments in experiment 2, showing that inclusion of low-oil DDGS in feed does not have a negative impact on this productive parameter. Similarly, Guney et al. ${ }^{15}$ supplemented broiler chick diets with either 10\% or 20\% of low-oil DDGS (7.52\% and 6.74\% of oil content, respectively), and found no negative effects on growth performance of birds. Further, an $8 \%$ inclusion of conventional DDGS in feed did not affect weight gain of chicks from 0 to $14 \mathrm{~d}$ of age, but it did however negatively affect feed conversion. ${ }^{16}$ In contrast, other studies found that a $16 \%$ or $24 \%$ inclusion of conventional DDGS in starter chick diets improves weight gain of birds. ${ }^{17}$ Conversely, Lumpkins et al. ${ }^{18}$ show that an $18 \%$ supplementation of conventional DDGS, resulted in a decrease in growth rate.

Phosphorus bioavailability for each DDGS used to supplement diets in this work was similar to that reported in previous studies (75\%-80\%). ${ }^{4,14}$ Moreover, inclusion percentages of $\mathrm{P}$ in diets formulated for this study are similar to those used by Martinez et al..$^{5}$ who established that these values were higher than those needed to comply with broiler chick diet requirements published by the NRC ${ }^{19}$ (based both on total and non-phytate $\mathrm{P}$ ). However, there are other studies that report a lower $\mathrm{P}$ bioavailability rate (66\%) for low-oil DDGS. ${ }^{20}$

Data for apparent ileal CP and AA digestibility in this study agree with other work where AA digestibility was determined in conventional DDGS, with percentages ranging from $54.8-77 \%$ for lysine and $77.5 \%-86.9 \%$ for methionine. ${ }^{6,21-25}$ To date, few studies have assessed AA digestibility in low-oil DDGS, however, Wamsley et al. 20 found a 65\% digestibility for lysine in Cobb 500 chickens fed with a low-oil DDGS supplemented diet and 88\%, respectively.

Average apparent metabolizable energy values obtained from excreta of birds in this study (2828 and $2854 \mathrm{kcal} / \mathrm{kg}$ for DDGS-A and B respectively), were similar to those found in other work with either sorghum or corn-soybean based diets, supplemented with varying percentages of low oil or conventional DDGS.21,24,26${ }^{28}$ Moreover, Adeola and Zhai ${ }^{28}$ found ileal digestible energy values of 2841 and $2659 \mathrm{kcal} / \mathrm{kg}$ in corn-soybean meal diets containing $30 \%$ or $60 \%$ of conventional DDGS respectively. 
Table 6. Total amino acid content (\%), digestibility coefficients (\%) and AMEn on a dry matter basis (Kcal/kg), of diets supplemented with two low-oil distillers dried grains with solubles (DDGS). Assessed in ileal content of $21 \mathrm{~d}$ old broiler chicks.

\begin{tabular}{|l|c|c|c|c|}
\hline \multicolumn{1}{|c|}{ Amino acid, \% } & \multicolumn{3}{|c|}{ DDGS-A } & \multicolumn{2}{c|}{ DDGS-B } \\
\hline & Total, \% & $\begin{array}{c}\text { Digestibility } \\
\text { coefficient, \% }\end{array}$ & Total, \% & $\begin{array}{c}\text { Digestibility } \\
\text { coefficient, \% }\end{array}$ \\
\hline Methionine & 0.55 & 85.3 & 0.57 & 84.7 \\
\hline Cystine & 0.48 & 76.6 & 0.49 & 75.0 \\
\hline Lysine & 1.00 & 65.4 & 0.98 & 64.6 \\
\hline Threonine & 0.93 & 63.2 & 0.96 & 64.1 \\
\hline Arginine & 1.17 & 77.0 & 1.11 & 77.7 \\
\hline Leucine & 3.15 & 86.7 & 3.34 & 84.0 \\
\hline Isoleucine & 1.07 & 77.8 & 1.08 & 77.8 \\
\hline Valine & 1.11 & 74.4 & 1.16 & 77.3 \\
\hline Phenylalanine & 1.35 & 81.9 & 1.34 & 81.7 \\
\hline Histidine & 0.80 & 77.0 & 0.83 & 77.4 \\
\hline Protein & 28.05 & 76.5 & 27.02 & 76.4 \\
\hline AME $\mathrm{n}^{\prime}$ kcal/kg & \multicolumn{2}{|c|}{2828} & & 2854 \\
\hline
\end{tabular}

\section{Conclusion}

Bioavailability of $\mathrm{P}$ in the low oil DDGS samples used in this study (DDGS A 6.54\% and DDGS B 5.39\% of oil content) was 72\% and $86 \%$, respectively. Apparent ileal AA digestibility coefficients (methionine, cysteine, lysine, threonine, arginine, leucine, isoleucine, valine, phenylalanine, and histidine) were similar for the two assessed DDGS. The average apparent ileal amino acid digestibility coefficient for DDGS A $76.5 \%$ and $B$ was $76.4 \%$. The $\mathrm{AME}_{\mathrm{n}}$ values on a dry matter basis were 2828 and $2854 \mathrm{kcal} / \mathrm{kg}$ for DDGS A and B, respectively. 


\section{Acknowledgements}

Authors wish to thank UNAM for academic support, CEIEPAv-FMVZ-UNAM for funding, and ADM Department of Animal Nutrition for assistance in field work. Authors also thank Drs. Jorge Miguel Iriarte and Alma Selene Vázquez Delgado for field work assistance.

\section{Conflicts of interest}

Authors declare that there is no conflict of interest regarding publication of this article.

\section{Author contributions}

C. C. A.: experiment design, field work, statistical analysis, final document preparation; J. A.: statistical analysis of data. E. A.: statistical analysis of data, final document preparation; C. L.: experiment design, statistical analysis.

\section{References}

1. NCGA, USA. National Corn Growers Association. World of Corn 2018. Available from: www.ncga.com/www.worldofcorn.com.

2. Rosentrater KA, Ilelegi KM, Johnson DB. Manufacturing of fuel ethanol and distiller's grains-Currents and evolving processes. $1^{\text {st. }}$ ed. Boca Raton, Fl: CRC Press; 2011.

3. Kim EJ, Martínez-Amezcua C, Utterback PL, Parsons CM. Phosphorus bioavailability, true metabolizable energy, and amino acid digestibilities of high protein corn distillers dried grains and dehydrated corn germ. Poult Sci. 2008;87:700-5.

4. Lumpkins BS, Batal AB. The bioavailability of lysine and phosphorus in distillers dried grains with solubles. Poult Sci. 2005;84:581-6.

5. Martínez-Amezcua C, Parsons CM, Noll SL. Content and relative bioavailability of phosphorus in distillers dried grains with soluble in chicks. Poult Sci. 2004;83: 971-6.

6. Pahm AA, Scherer CS, Pettigrew JE, Baker DH, Parsons CM, Stein HH. Standardized amino acid digestibility in cecectomized roosters and lysine bioavailability in chicks fed distillers dried grains with soluble. Poult Sci. 2009;88:571-8.

7. Cortes CA, Ramírez ES, Arce MJ, Avila GE, López CC. Effect of feeding low oil DDGS to laying hens and broiler chickens on performance and egg yolk and skin pigmentation. Brazilian J Poult Sci. 2015;17:247-54.

8. Association of Official Analytical Chemists. Official Methods of Analysis of AOAC International. 18 $18^{\text {th }}$ ed. Gaithersburg, MD: AOAC Int.; 2006.

9. AVIAGEN Ross-broiler performance objetives manual. Huntsville: Aviagen Group; 2017. Available from: www.aviagen.com

10. Leeson S, Summers JD. Scott's Nutrition of the chicken. $4^{\text {th }}$ ed. Guelph, Ontario: University Books, 2001.

11. Lomer MCC, Thomson RPH, Commiso J, Keen CL, Powel JJ. Determination of titanium dioxide in foods using inductively coupled plasma optical emission spectrometry. Anal Lond. 2000;125:2339-49.

12. Llames CR, Fontaine J. Determination of amino acids in feeds: Collaborative study. J AOAC Int. 1994;77:1362-402.

13. SPSS Inc. SPSS Software for Windows (computer program) version 17.0 SPSS, Inc.; 2012. 
14. Martinez-Amezcua C, Parsons CM, Baker DH. Effect of microbial phytase and citric acid on phosphorus bioavailability, apparent metabolizable energy, and amino acid digestibility in distillers dried grains with soluble in chicks. Poult Sci. 2006;85:470-5.

15. Guney AC, Shim MY, Batal AB, Dale NM, Pesti GM. Effect of feeding low-oil distillers dried grains with soluble on the performance of broilers. Poult Sci. 2013;92:2070-6.

16. Loar RE, Donaldson JR, Corzo A. Effects of feeding distillers dried grains with soluble to broilers from 0 to 42 days posthatch on broiler performance, carcass characteristics, and selected intestinal characteristics. J Appl Poult Res. 2012;21:48-62.

17. Shim MY, Pesti GM, Bakalli Rl, Tillman PB, Payne RL. Evaluation of corn distillers dried grains with soluble as an alternative ingredient for broilers. Poult Sci. 2001;90:369-76.

18. Lumpkins BS, Batal AB, Dale NM. Evaluation of distillers dried grains with soluble as a feed ingredient for broilers. Poult Sci. 2004;83:1891-6.

19. National Research Councill. Nutrient Requirements of Poultry. $9^{\text {th }}$ rev. ed. Washington DC: National Academy Press; 1994.

20. Wamsley KGS, Loar RE II, Karges K, Moritz JS. The use of practical diets and regression analyses to determine the utilization of lysine and phosphorus in corn distillers dried grains and soluble using Cobb 500 male broilers. J Appl Poult Res. 2013;22: 279-97.

21. Batal AB, Dale NM. True metabolizable energy and amino acid digestibility of distillers dried grains with soluble. J Appl Poult Res. 2006;15: 89-93.

22. Fastinger ND, Latshaw JD, Mahan DC. Amino acid availability and true metabolizable energy content of corn distillers dried grains with soluble in adult cecectomized roosters. Poult Sci. 2006;85:1212-6.

23. Kim EJ, Utterback PL, Parsons CM. Comparison of amino acid digestibility coefficients for corn gluten meal, and corn distillers grains with soluble among 3 different bioassays. Poult Sci. 2012;91: 3141-7.

24. Kim EJ, Parsons CM, Srinivasan R, Singh V. Nutritional composition, nitrogen-corrected true metabolizable energy, and amino acid digestibilities of new corn distillers dried grains with soluble produced by new fractionation processes. Poult Sci. 2010;89:44-51.

25. Martinez-Amezcua C, Parsons CM, Singh V, Srinivasan R, Murthy GS. Nutritional characteristics of corn distillers dried grains with soluble as affected by the amounts of grains versus soluble and different processing techniques. Poult Sci. 2007;86:2624-30.

26. Meloche KJ, Kerr BJ, Shurson GC, Dozier WA III. Apparent metabolizable energy and prediction equations for reduced-oil corn distillers dried grains with soluble in broiler chicks from 10 to 18 days of age. Poult Sci. 2013;92:3176-83.

27. Rochell SJ, Kerr BJ, Dozier WA III. Energy determination of co-product fed to broiler chicks from 15 to 24 days of age, and use of composition analysis to predict nitrogen-corrected apparent metabolizable energy. Poult Sci. 2011;90:1999-2007.

28. Adeola $\mathrm{O}$, Zhai $\mathrm{H}$. Metabolizable energy value of dried corn distillers grains and corn distillers grains with soluble for 6-week-old broiler chickens. Poult Sci. 2012;91:712-8. 